\title{
The effects of mother's education on achieving exclusive breastfeeding in Indonesia
}

\author{
Agung Dwi Laksono ${ }^{1,2}$, Ratna Dwi Wulandari ${ }^{3^{*}}$ (D, Mursyidul Ibad ${ }^{4}$ and Ina Kusrini ${ }^{5}$
}

\begin{abstract}
Background: Even though the Indonesian government have set regulations for maintaining exclusive breastfeeding practices, the coverage remains low. The study aims to analyze the effects of mother's education level on the coverage of exclusive breastfeeding in Indonesia.

Methods: This study used data from the 2017 Nutrition Status Monitoring Survey. It covered data of 53,528 children under 5 years old (7-59 months) as the samples. Variables included exclusive breastfeeding status, mother's education level, mother's age, marital status, employment status, gender, residence, under five's age and gender. A binary logistics regression was performed in the final test.

Results: Mothers who graduated from elementary school were 1.167 times more likely to perform exclusive breastfeeding compared to mothers who never attended schools. Additionally, those who graduated from junior high school had 1.203 times possibilities to give exclusive breastfeeding compared to mothers without educational records. While, mothers who graduated from high school were 1.177 times more likely to perform exclusive breastfeeding compared to those without educational records. Mothers who graduated from tertiary education had 1.203 times more possibilities to perform exclusive breastfeeding compared to mothers who were never enrolled to schools. Other variables also became affecting predictors on exclusive breastfeeding, such as mother's age, mother's employment status, child's age, and residence.
\end{abstract}

Conclusions: The mother's education level positively affects exclusive breastfeeding practice in Indonesia.

Keywords: Breastfeeding, Exclusive breastfeeding, Education level, Nutrition education, Health education

\section{Background}

Breastfeeding is a common method of providing breast milk as food supply for infants and young children. It is the cheapest and simplest method to meet the baby's nutritional needs. Breast milk will improve sensory and cognitive abilities and protect children from infectious and chronic diseases. Poor infant feeding practices may impact on children's growth and development [1, 2]. A meta-analysis study used 17 previous studies that

\footnotetext{
* Correspondence: ratna-d-w@fkm.unair.ac.id

${ }^{3}$ Faculty of Public Health, Universitas Airlangga, Surabaya, Indonesia

Full list of author information is available at the end of the article
}

discover an increase in IQ scores of 3.44 points in breastfed children. Meanwhile, in the meta-regression, none of the studies explained the heterogeneity [3].

Exclusive breastfeeding (EBF) is a method of giving breast milk merely for infants to provide complete nutrition in the first 6 months of life [4]. Exclusive breastfeeding has many benefits for mothers and babies. For babies, EBF can reduce infant mortality due to common infectious diseases, help recovery, and increase children immunity. Regarding its benefits for mothers, EBF is a safe feeding method that can protect mothers from the risk of ovarian and brceast cancer and reduce obesity [5-7].

C C The Author(s). 2021 Open Access This article is licensed under a Creative Commons Attribution 4.0 International License, which permits use, sharing, adaptation, distribution and reproduction in any medium or format, as long as you give appropriate credit to the original author(s) and the source, provide a link to the Creative Commons licence, and indicate if changes were made. The images or other third party material in this article are included in the article's Creative Commons licence, unless indicated otherwise in a credit line to the material. If material is not included in the article's Creative Commons licence and your intended use is not permitted by statutory regulation or exceeds the permitted use, you will need to obtain permission directly from the copyright holder. To view a copy of this licence, visit http://creativecommons.org/licenses/by/4.0/ The Creative Commons Public Domain Dedication waiver (http://creativecommons.org/publicdomain/zero/1.0/) applies to the data made available in this article, unless otherwise stated in a credit line to the data. 
Although EBF has been proven to a positive a positive effect $[3,8,9]$, the coverage of EBF is still very low. Globally, the coverage of EBF was $30-50 \%$ [1], but was around $35.7 \%$ in Indonesia [10]. Previous studies have identified intrinsic and extrinsic factors that affect EBF. Despite having regulations to maintain EBF practices (Law Number 36/2009 concerning Health), the coverage of EBF in Indonesia remains low, especially for uneducated and employed mothers [11].

The low coverage has something to do with traditional breastfeeding practices in native Indonesian tribes. Some native tribes introduce food or drinks to babies who are recently a few days old. The Gayo, Javanese, and Muyu tribes commonly feed their babies honey, sugar water, and sago solution [12-15].

Based on the background, this study aimed to analyze the effects of mother's education on exclusive breastfeeding practice in Indonesia. The results of this study vitally become basic references for policymakers to formulate policies in improving the coverage of EBF in Indonesia.

\section{Methods}

\section{Data source}

This study utilized raw data of the 2017 Nutrition Status Monitoring Survey. This survey was a national survey using a multi-stage cluster random sampling method and was conducted by the Directorate of Community Nutrition of the Indonesian Ministry of Health [10]. The survey population was all children under 5 years old or 7-59 months in Indonesia, and there were 53,528 babies as the samples.

\section{Data analysis}

Mother's education level was to which degree a mother has ever completed an education. It has five categories, such as not attending school, primary school, junior high school, senior high school, and tertiary education. Another variable was mother's employment status, which defines a type of mother's work or employment.

The dependent variable in this study was exclusive breastfeeding practice. Seven independent variables were divided into 3 groups. The first variable was the characteristics of mothers (education level, age, marital status, employment status). The second variable was the characteristics of the children under five (age and gender). Finally, the third was a residence (urban-rural).

The Chi-Square test was utilized to test the dichotomous variables, while continuous variables were tested using the T-test. This statistical test assessed whether there was a statistically significant relationship between mother's education level variable and another variable. Besides, a binary logistic regression test was performed at the final stage to identify disparities in the contribution of mother's education levels to EBF practices in Indonesia. All data analyses were performed in SPSS 22 version software.

\section{Results}

Figure 1 shows the distribution of breastfed children under five by Indonesian provinces. It indicates the largest coverage of EBF in Java.

\section{Descriptive statistics}

Prior to a binary logistic regression test, a co-linearity test was carried out. The results of co-linearity test show that there was no co-linearity between dependent and independent variables. Table 1 shows that the tolerance value of all variables was greater than 0.10 , and the VIF value for all variables was less than 10.00. Based on the result of multicollinearity test, there were no symptoms of multicollinearity in the regression model.

Table 2 explains the statistical description of mother's education level. The table points out mothers in all categories of education level mostly did not breastfeed their children. It means the practice of EBF in all education categories was relatively low.

In Table 2, mothers who had primary education record are slightly older than mothers with other education levels. The majority of the mothers were married, but most mothers in four education levels were unemployed. Only mothers with tertiary education record were dominantly employed (65.52\%).

Table 2 informs that there was a significant relationship between education levels and babies' age. Based on babies' gender, male babies were dominant in all education categories. However, the test results stated that the relationship between mother's education level and babies' gender was not statistically significant. This study also reveals most mothers lived in rural areas. This variable was proven statistically significant to affect the practice of EBF.

\section{Multivariate regression analysis}

Table 3 shows the results of the binary logistic regression test that used "No EBF" as a reference.

It informs that all three groups of variables significantly affected the practice of EBF. Those affecting variables were mother's age, mother's education level, mother's employment status, babies' age, and residence.

This study finds mothers who graduated from primary school were 1.167 times more likely to perform EBF compared to mothers without education records (OR 1.167; 95\% CI 1.026-1.328). Those who graduated from junior high school had 1.203 times possibilities to perform EBF compared to those who never attended schools (OR 1.203; 95\% CI 1.057-1.368). Mothers who are high school graduates were 1.177 times more likely 


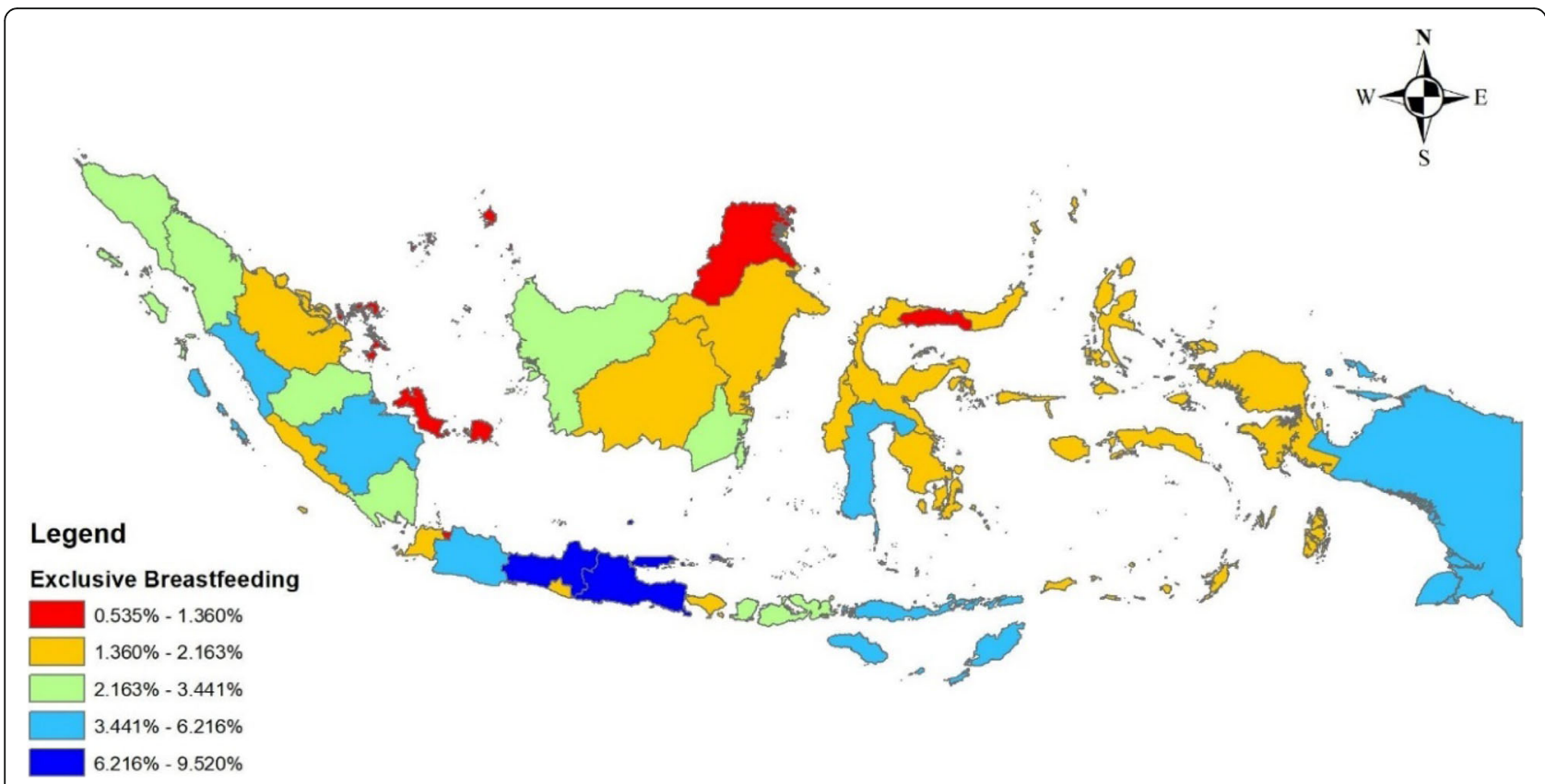

Fig. 1 Distribution of EBF among under five (7-59 months) by provinces in Indonesia, the IDHS 2017. Source: The map depicted in the image belongs to the author

to perform EBF than mothers without formal education experience (OR 1.177; 95\% CI 1.037-1.335). Additionally, mothers with tertiary education record had 1.203 times possibilities to give EBF than mothers without formal education record (OR 1.231; 95\% CI 1.073-1.411).

Children under five whose mothers were employed had 0.954 times more likely to be breastfed those whose mothers were unemployed (OR 0.954; 95\% CI 0.9130.997). Table 3 also shows that children under five in urban areas had 1.138 times possibilities to perform EBF than those in rural areas (OR 1.138; 95\% CI 1.0921.186).

Table 1 Results for a co-linearity test of EBF in Indonesia $(n=53,528)$

\begin{tabular}{lll}
\hline Variables & \multicolumn{2}{l}{ Collinearity Statistics } \\
\cline { 2 - 3 } & Tolerance & VIF \\
\hline Mother's Characteristics & 0.958 & 1.044 \\
Education level & 0.978 & 1.022 \\
Age (in years; mean) & 0.997 & 1.003 \\
Marital status & 0.980 & 1.020 \\
Employment Status & & \\
Under five's Characteristic & 0.997 & 1.003 \\
$\quad$ Under five's Age (in months; mean) & 1.000 & 1.000 \\
$\quad$ Under five's Gender & 0.969 & 1.032 \\
Residence &
\end{tabular}

*Dependent Variable: EBF status

\section{Discussion}

This study discovers that mother's education affected the practice of EBF in Indonesia. A better education tends to give mothers more possibilities of EBF. This finding is in line with findings of other studies $[16,17]$. The surveys to postnatal mothers in Nigeria and China show better education positively contributed to the breastfeeding process and the rate level of EBF $[16,17]$. Some studies in America added self-efficacy as a variable to find the correlation of maternal education and the practice of EBF. Higher education levels were correlated with better self-efficacy scores. Mother's education level had a positive relationship with the practice of EBF $[8,9]$.

Similarly, another study in European multiregions finds that mothers who were younger and less educated were more likely to stop breastfeeding before their babies were aged 6 months. In other words, they did not perform complete EBF. Education level, parity, and socioeconomic factors could indicate whether mothers breastfeed or not their babies [18]. Some studies in Chile also found psychosocial factors, such as maternal IQ and low-risk prenatal behavior at birth, could affect the duration of breastfeeding $[19,20]$. Another study conducted in Eastern Indonesia, which analyzed data of the 2012 Indonesian Family Life Survey, concluded the same thing. This study took a smaller sample size (1138 under five) and found that mother's education levels had a positive effect on the success rates of EBF [21].

Moreover, this study uncovers unemployed mothers had better EBF practice. This result is similar to the 
Table 2 Descriptive Statistics of Mother's Education Level and Related Variables $(n=53,528)$

\begin{tabular}{|c|c|c|c|c|c|c|c|}
\hline \multirow[t]{2}{*}{ Variables } & \multicolumn{5}{|c|}{ Mother's Education level } & \multirow[t]{2}{*}{ All } & \multirow[t]{2}{*}{$P$} \\
\hline & No School & Primary School & Junior High School & Senior High School & College & & \\
\hline EBF status & & & & & & & $0.013^{*}$ \\
\hline - $\mathrm{EBF}$ & 367 (29.84\%) & 4063 (34.12\%) & 4066 (34.49\%) & $8180(34.15 \%)$ & $1632(35.13 \%)$ & $18,308(34.20 \%)$ & \\
\hline - Not EBF (Ref.) & $863(70.16 \%)$ & $7846(65.88 \%)$ & 7723 (65.51\%) & $15,774(65.85 \%)$ & $3014(64.87 \%)$ & 35,220 (65.80\%) & \\
\hline \multicolumn{8}{|l|}{ Mother's Characteristics } \\
\hline Age (in years; mean) & $1230(28.48)$ & $11,909(31.07)$ & $11,789(29.07)$ & $23,594(28.50)$ & $4646(30.06)$ & $53,528(29.33)$ & $\leq 0.001^{*}$ \\
\hline Marital status & & & & & & & $\leq 0.001^{*}$ \\
\hline - Single (Ref.) & $5(0.41 \%)$ & $53(0.45 \%)$ & $46(0.39 \%)$ & $82(0.34 \%)$ & $18(0.39 \%)$ & $204(0.38 \%)$ & \\
\hline - Married & 1208 (98.21\%) & $11,719(98.40 \%)$ & $11,622(98.58 \%)$ & 23,731 (99.07\%) & 4606 (99.14\%) & $52,886(98.80 \%)$ & \\
\hline - Divorce & $17(1.38 \%)$ & $137(1.16 \%)$ & $121(1.03 \%)$ & $141(0.59 \%)$ & $22(0.47 \%)$ & $438(0.82 \%)$ & \\
\hline Employment Status & & & & & & & $\leq 0.001^{*}$ \\
\hline - Unemployed (Ref.) & $617(50.16 \%)$ & 9077 (76.22\%) & $9323(79.08 \%)$ & 19,867 (82.94\%) & $1602(34.48 \%)$ & $40,486(75.64 \%)$ & \\
\hline - Employed & $613(49.84 \%)$ & $2832(23.78 \%)$ & $2466(20.92 \%)$ & $4087(17.06 \%)$ & 3044 (65.52\%) & $13,042(24.36 \%)$ & \\
\hline \multicolumn{8}{|l|}{ Under five's Characteristic } \\
\hline Age (in months; mean) & $1230(14.66)$ & $11,909(14.81)$ & $11,789(14.76)$ & $23,594(14.53)$ & $4646(14.69)$ & $53,528(14.66)$ & $\leq 0.001^{*}$ \\
\hline Gender & & & & & & & 0.605 \\
\hline - Male & 641 (52.11\%) & 5987 (50.27\%) & 5993 (50.84\%) & $12,180(50.85 \%)$ & 2367 (50.95\%) & 27,168 (50.75\%) & \\
\hline - Female (Ref.) & 589 (47.89\%) & 5922 (49.73\%) & 5793 (49.14\%) & $11,771(49.14 \%)$ & 2279 (49.05\%) & 26,354 (49.23\%) & \\
\hline Residence & & & & & & & $\leq 0.001^{*}$ \\
\hline - Urban & 167 (13.58\%) & 1989 (16.70\%) & 2392 (20.29\%) & 7559 (31.56\%) & 1583 (34.07\%) & $13,690(25.58 \%)$ & \\
\hline - Rural (Ref.) & 1063 (86.42\%) & 9920 (83.30\%) & 9397 (79.71\%) & 16,395 (68.44\%) & 3063 (65.93\%) & 39,838 (74.42\%) & \\
\hline
\end{tabular}

Note: Chi-Square used for dichotomous variables and the T-test used for continuous variables. *Significant at the $95 \%$ level

Table 3 Results of Binary Logistic Regression ( $n=53,528$ )

\begin{tabular}{|c|c|c|c|c|}
\hline \multirow[t]{2}{*}{ Predictors } & \multirow[t]{2}{*}{ Sig. } & \multicolumn{3}{|l|}{ EBF } \\
\hline & & OR & Lower Bound & Upper Bound \\
\hline \multicolumn{5}{|l|}{ Mother's Characteristics } \\
\hline Education level: no school & - & - & - & - \\
\hline Education level: primary school & $0.019^{\mathrm{a}}$ & 1.167 & 1.026 & 1.328 \\
\hline Education level: junior high school & $0.005^{\mathrm{a}}$ & 1.203 & 1.057 & 1.368 \\
\hline Education level: senior high school & $0.011^{\mathrm{a}}$ & 1.177 & 1.037 & 1.335 \\
\hline Education level: college & $0.003^{\mathrm{a}}$ & 1.231 & 1.073 & 1.411 \\
\hline Age & $\leq 0.001^{\mathrm{a}}$ & 1.009 & 1.006 & 1.012 \\
\hline Marital Status: single & - & - & - & - \\
\hline Marital Status: married & 0.561 & 1.092 & 0.812 & 1.468 \\
\hline Marital Status: divorced & 0.817 & 0.959 & 0.670 & 1.371 \\
\hline Employment status: unemployed & - & - & - & - \\
\hline Employment status: employed & $0.038^{\mathrm{a}}$ & 0.954 & 0.913 & 0.997 \\
\hline \multicolumn{5}{|l|}{ Toddler's Characteristic } \\
\hline Age & $\leq 0.001^{a}$ & 1.022 & 1.018 & 1.026 \\
\hline \multicolumn{5}{|l|}{ Residence } \\
\hline Area: Urban & $\leq 0.001^{a}$ & 1.138 & 1.092 & 1.186 \\
\hline Area: Rural & - & - & - & - \\
\hline
\end{tabular}


results of other studies indicating employed mothers were less likely to perform EBF. They tend to have less time and opportunity to interact with children, including giving breastfeed to their children [21, 22]. Studies in Qatar and Ethiopia find that the employment status was one of the barriers to the success of EBF. Plausibly mothers must return to work immediately after the maternity leave period runs out [23, 24]. Having flexible work schedules and workplace proximity to home can assist the sustainability of breastfeeding [25].

Another study carried out in Vietnam indicates that teamwork parenting could increase the success of EBF. In this study, husband's role was also observed to be one of the predictors of EBF success [26]. Supporting this fact, RCT research in Canada finds collaboration between parents influenced knowledge, perceptions, practices, and duration of EBF [27]. In India, social support became one of the determinants of EBF success [1].

This present study, furthermore, shows that children under five in urban areas had a better EBF intake. This is probably due to better information exposure about the benefits of EBF in urban areas than in rural areas. The effect of information exposure that may improve mother's knowledge about EBF was proven as one determinant of EBF success by several studies [17, 21, 28, 29]. In Indonesia, urban areas tend to have better access to health services and information than rural areas, and this leads to higher coverage of health programs [30,31].

To end this discussion, this study also suggests the government to formulate policies focusing on clear targets to be achieved by referring to these study findings. It can target mothers who have poor education, are employed, and live in rural areas. Policies focusing on these targets need to be implemented for a wider coverage of EBF.

\section{Limitation}

The study utilized big data of the 2017 IDHS survey. The data are not presenting facts deeply so that the findings in this study have not captured different phenomena in the number of indigenous Indonesians, who have their local wisdom of breastfeeding practices. Mother's cultural background can be an adequate differentiator $[12,14,32]$. Besides, the study also did not involve the participation of parents, parents-in-law, and family to indicate the practice of EBF. While, previous studies find this variable could affect EBF [32, 33]. It is necessary to conduct further qualitative studies to capture or deepen some phenomena in question.

\section{Conclusions}

It could be concluded that there was a positive effect of mother's education on the practice of EBF in Indonesia. Other variables, such as mother's age, mother's employment status, babies' age, and residence were some predictors of EBF success rates in Indonesia.

The government needs to issue policies that focus on specific targets as identified in this study. It can target mothers who have poor education, are employed, and live in rural areas to expand the coverage of EBF in Indonesia.

\section{Acknowledgments \\ The author would like to thank the Directorate of Community Nutrition of the Ministry of Health of the Republic of Indonesia for allowing to processing of data of the 2017 Indonesia Nutritional Status Monitoring.}

\section{Authors' contributions}

ADL developed the proposal, analyzed, and interpreted the patient data. RDW, MI, and IK was a major contributor in conducting the study, interpreting the data, and writing the manuscript. The authors read and approved the final manuscript.

\section{Funding}

Not applicable.

\section{Availability of data and materials}

The 2017 Nutrition Status Monitoring Survey data used to support these findings of this study were supplied by the Directorate of Community Nutrition of the Indonesian Ministry of Health under license and so can not be made freely available. Requests for access to these data should be made to the Directorate of Community Nutrition of the Indonesian Ministry of Health.

\section{Ethics approval and consent to participate}

The Nutrition Status Monitoring Survey in 2017 has an ethical license approved by the Health Research Ethics Commission at the Indonesian Ministry of Health (ethics number: LB.02.01/2/KE.244/2017). In this survey, informed consent was used during data collection, which considers aspects of procedures for data collection, voluntary, and confidentiality. Respondents gave written consent.

\section{Consent for publication}

Not applicable.

\section{Competing interests}

The authors declare that they have no competing interests.

\section{Author details}

'National Institute of Health Research and Development, the Ministry of Health of the Republic of Indonesia, Jakarta, Indonesia. 'Doctoral Program, Faculty of Public Health, University of Airlangga, Surabaya, Indonesia. ${ }^{3}$ Faculty of Public Health, Universitas Airlangga, Surabaya, Indonesia. ${ }^{4}$ Faculty of Health, Nadlatul Ulama University, Surabaya, Indonesia. ${ }^{5}$ Unit of Health Research and Development Magelang, Ministry of Health, Center Java, Java, Indonesia.

Received: 1 July 2020 Accepted: 8 December 2020

Published online: 06 January 2021

\section{References}

1. Pareek S. Exclusive breastfeeding in India: an ultimate need of infants. Nurs Pract Today. 2019:6(1):4-6.

2. Binda V, Figueroa-Leigh F, Olhaberry M. Low quality of mother-child interaction in infants at psychosocial risk is associated with risk of developmental delay. Rev Chil Pediatr. 2019;90(3):260-6.

3. Horta BL, de Mola CL, Victora CG. Breastfeeding and intelligence: a systematic review and meta-analysis. Acta Paediatr. 2015;104(467):14-9.

4. Charlick SJ, McKellar L, Gordon AL, Pincombe J. The private journey: an interpretative phenomenological analysis of exclusive breastfeeding. Women Birth. 2019;32(1):e34-42.

5. Arikawa S, Rollins N, Jourdain G, Humphrey J, Kourtis AP, Hoffman I, et al. Contribution of maternal antiretroviral therapy and breastfeeding to 24- 
month survival in human immunodeficiency virus-exposed uninfected children: an individual pooled analysis of African and Asian studies. Clin Infect Dis. 2018;66(11):1668-77.

6. MacVicar S, Humphrey T, Forbes-McKay KE. Breastfeeding and the substance-exposed mother and baby. Birth. 2018;45(4):450-8.

7. Fan HSL, Wong JYH, Fong DYT, Lok KYW, Tarrant M. Breastfeeding outcomes among early-term and full-term infants. Midwifery. 2019;71:71-6.

8. Glassman ME, McKearney K, Saslaw M, Sirota DR. Impact of breastfeeding self-efficacy and sociocultural factors on early breastfeeding in an urban, predominantly Dominican community. Breastfeed Med. 2014;9(6):301-7.

9. Bahorski JS, Childs GD, Loan LA, Azuero A, Morrison SA, Chandler-Laney PC, et al. Self-efficacy, infant feeding practices, and infant weight gain: an integrative review. J Child Health Care. 2019;23(2):286-310.

10. Directorate of Community Nutrition of The Ministry of Health of The Republic of Indonesia. The 2017 Indonesia Nutritional Status Monitoring (Pemantauan Status Gizi 2017) [Internet]. Jakarta; 2017. Available from: http://www.kesmas.kemkes.go.id/assets/upload/dir_519d41d8cd98f00/files/ Buku-Saku-Nasional-PSG-2017_975.pdf.

11. Ratnasari D, Paramashanti BA, Hadi H, Yugistyowati A, Astiti D, Nurhayati E. Family support and exclusive breastfeeding among Yogyakarta mothers in employment. Asia Pac J Clin Nutr. 2017;26:S31-5.

12. Pratiwi NL, Fitrianti $Y$, Nuraini $S$, Rachmawati $T$, Laksono AD, Afreni $M$, et al Concealed pregnant women or Kemel of Gayo ethnic in Blang Pegayon District, Gayo Lues District, Aceh. Bull Heal Syst Res. 2019;22(2):81-90.

13. Laksono AD, Faizin K, Raunsay EM, Soerachman R. Muyu women in exile (Perempuan Muyu dalam Pengasingan) [internet]. Jakarta: Lembaga Penerbitan Balitbangkes; 2014. Available from: https://www.scribd.com/ doc/261673624/Perempuan-Muyu-dalam-Pengasingan-Riset-EthnografiKesehatan-2014-Boven-Digoel.

14. Laksono AD, Soerachman R, Angkasawati TJ. Case study of Muyu Ethnic's maternal health in Mindiptara District-Boven Digoel (Studi Kasus Kesehatan maternal Suku Muyu di Distrik Mindiptana, Kabupaten Boven Digoel). J Reprod Heal. 2016;07/03:145-55.

15. Maghfiroh MS, Laksono AD. Given sugar water ... "at first the cry became silent, because it was full, not limp, its endurance increased"; study of patterns of infant intake ("Diberi air gula ... awalnya nangis menjadi diam, karena kenyang, gak lemas, daya tahan tubuhnya meningkat"). S Amerta Nutr. 2020;4(2):116-22.

16. Agho KE, Ogeleka P, Ogbo FA, Ezeh OK, Eastwood J, Page A. Trends and predictors of prelacteal feeding practices in Nigeria (2003-2013). Nutrients. 2016;8(8):462.

17. Hamze L, Mao J, Reifsnider E. Knowledge and attitudes towards breastfeeding practices: a cross-sectional survey of postnatal mothers in China. Midwifery. 2019;74:68-75.

18. Bonnet C, Blondel B, Piedvache A, Wilson E, Bonamy A-KE, Gortner L, et al. Low breastfeeding continuation to 6 months for very preterm infants: a European multiregional cohort study. Matern Child Nutr. 2019;15(1):e12657.

19. Farkas C, Girard L-C. Breastfeeding initiation and duration in Chile: understanding the social and health determinants. J Epidemiol Community Health. 2019;73(7):637.

20. Girard L-C, Farkas C. Breastfeeding and behavioural problems: propensity score matching with a national cohort of infants in Chile. BMJ Open. 2019; 9(2):e025058.

21. Bue MCL, Priebe J. Revisiting the socioeconomic determinants of exclusive breastfeeding practices: evidence from eastern Indonesia. Oxford Dev Stud. 2018;46(3):398-410.

22. Laksono AD, Ibad M, Mursita A, Kusrini I, Wulandari RD. Characteristics of mother as predictors of stunting in toddler. Pak J Nutr. 2019;18(12):1101-6.

23. Hendaus MA, Alhammadi AH, Khan S, Osman S, Hamad A. Breastfeeding rates and barriers: a report from the state of Qatar. Int J Womens Health. 2018;10:467-75.

24. Tadesse F, Alemayehu $Y$, Shine $S$, Asresahegn $H$, Tadesse T. Exclusive breastfeeding and maternal employment among mothers of infants from three to five months old in the Fafan zone, Somali regional state of Ethiopia: a comparative cross-sectional study. BMC Public Health. 2019;19(1): 1015.

25. Chen J, Xin T, Gaoshan J, Li Q, Zou K, Tan S, et al. The association between work related factors and breastfeeding practices among Chinese working mothers: a mixed-method approach. Int Breastfeed J. 2019;14(1):28.
26. Rempel JK, Rempel LA, Hoa DTP, Vui LT, Long TK. Parenting teamwork: the impact of a fathering intervention on mothers and infants in Vietnam. Child Dev. 2019;91(2):e345-e364. https://doi.org/10.1111/cdev.13244.

27. Abbass-Dick J, Stern SB, Nelson LE, Watson W, Dennis C-L. Coparenting breastfeeding support and exclusive breastfeeding: a randomized controlled trial. Pediatrics. 2015;135(1):102-10.

28. Buss IM. Knowledge, attitudes and behaviours towards exclusive breastfeeding amongst mothers in Sarawak, Malaysia: a qualitative study. Int Med J Malaysia. 2019;18(1):45-54.

29. Wulandari RD, Laksono AD. Does the place of residence affect the achievement of exclusive breastfeeding? A study in eastern Indonesia. Syst Rev Pharm. 2020;11(9):872-6.

30. Laksono AD, Wulandari RD, Soedirham O. Urban and rural disparities in hospital utilization among Indonesian adults. Iran J Public Health. 2019;48(2) 247-55.

31. Laksono AD, Wulandari RD. Urban-rural disparities of facility-based childbirth in Indonesia. In: 4th international symposium on Health Research (ISHR 2019) [internet]. Denpasar: Atlantis Press; 2020. p. 33-9. Available from: https://www.atlantis-press.com/proceedings/ishr-19/125935017.

32. Sutan $\mathrm{R}$, Berkat $\mathrm{S}$. Does cultural practice affects neonatal survival- a case control study among low birth weight babies in Aceh Province, Indonesia. BMC Pregnancy Childbirth. 2014;14(1):1-13.

33. Alianmoghaddam N, Phibbs S, Benn C. The impact of family culture on six months exclusive breastfeeding: a qualitative study in New Zealand. Breastfeed Rev. 2018;26(1):23-36.

\section{Publisher's Note}

Springer Nature remains neutral with regard to jurisdictional claims in published maps and institutional affiliations.
Ready to submit your research? Choose BMC and benefit from:

- fast, convenient online submission

- thorough peer review by experienced researchers in your field

- rapid publication on acceptance

- support for research data, including large and complex data types

- gold Open Access which fosters wider collaboration and increased citations

- maximum visibility for your research: over $100 \mathrm{M}$ website views per year

At $\mathrm{BMC}$, research is always in progress.

Learn more biomedcentral.com/submissions 